\title{
An Assessment of the NCEP Operational Global Spectral Model Forecasts and Analyses for Antarctica during FROST*
}

\author{
David H. Bromwich ${ }^{+}$and Richard I. Cullather $\#$ \\ Polar Meteorology Group, Byrd Polar Research Center, Ohio State University, Columbus, Ohio \\ ROBERT W. GRUMBINE \\ National Centers for Environmental Prediction, Camp Springs, Maryland
}

(Manuscript received 16 March 1998, in final form 10 March 1999)

\begin{abstract}
Analyses and medium-range numerical weather forecasts produced by the National Centers for Environmental Prediction are evaluated poleward of $50^{\circ} \mathrm{S}$ during the July 1994 special observing period of the Antarctic First Regional Observing Study of the Troposphere project. Over the Antarctic plateau, the poor representation of the continent's terrain creates ambiguity in assessing the quality of surface variables. An examination of the vertical temperature profile, however, finds the near-surface temperature inversion strength to be substantially smaller than the observed climatology at the zero forecast hour. This arises from surface temperatures that are warmer than expected. Significant adjustment occurs in a variety of fields over the first few days of the mediumrange forecast, which likely results from the initial hour's suspect temperature profile. A spatially oscillating series of forecast anomalies in the zonally averaged temperature cross section stretches to middle latitudes by day 3. Near-surface and upper-troposphere values are found actually to improve at the South Pole with forecast time, although some fields continue to adjust through day 7. Although the examination presented here does not give a complete diagnosis, differences between observations and analyses suggest deficiencies with the model initial fields have a major role in producing the substantial model drift found. Atmospheric moisture over the continental interior does not change significantly with forecast hour, although the distinct contrast between nearshore and interior conditions lessens with forecast time. A spurious high-latitude wave pattern is found for a variety of variables. The pattern of this distortion remains constant with forecast hour. Over the ocean, large forecast pressure and height differences with analyses are associated with blocking conditions. However, it is unclear whether this results from deficiencies in the forecast model or the meager observational network over the Southern Ocean.
\end{abstract}

\section{Introduction}

This paper provides a survey of results based on the evaluation of numerical analyses and forecasts produced by the National Centers for Environmental Prediction (NCEP, formerly known as the National Meteorological Center) during the July special observing period (SOP) of the Antarctic First Regional Observing Study of the Troposphere (FROST). The FROST project is an inter-

\footnotetext{
* Byrd Polar Research Center Contribution 1079.

+ Additional affiliation: Atmospheric Sciences Program, Department of Geography, Ohio State University, Columbus, Ohio.

\# Current affiliation: Department of Aerospace Engineering Sciences, University of Colorado, Boulder, Colorado.
}

Corresponding author address: David H. Bromwich, Polar Meteorology Group, Byrd Polar Research Center, Ohio State University, 1090 Carmack Road, Columbus, OH 43210-1002.

E-mail: Bromwich.1@osu.edu national collaboration of the Scientific Committee on Antarctic Research Working Group on Physics and Chemistry of the Atmosphere, with principal goals of examining the performance of operational analyses and forecasts for Antarctica and the surrounding sea-ice zone during three 1-month-long SOPs in July 1994, October-November 1994, and January 1995 (Turner et al. 1996). In high southern latitudes, weather data assimilation and prediction face an array of obstacles that limit operational performance, including the scarcity of available data and long-distance communications difficulties. Additionally, the sharp topographic contrasts and extreme weather conditions create unique difficulties in the numerical representation of the Antarctic atmosphere. The combination of these factors results in forecasts and analyses that are of poorer quality for Antarctica as compared to other parts of the world (Bourke 1996).

The U.S. component of FROST is an evaluation of analyses and forecasts produced by NCEP. There are 
several additional motivating factors for U.S. participation in FROST. First, the evaluation of forecast and analysis products at high southern latitudes enhances NCEP capabilities in hemispheric weather prediction, which extend to South America. Second, with the end of U.S. Navy's historic 42-year role in Antarctica in March 1998, many of the traditional support functions necessary for research activities are being transferred to civilian contractors (Augustine et al. 1997). This will ultimately lead to an increased reliance on civilian weather centers for the safe implementation of research activities on the Antarctic continent. Additionally, the use of atmospheric numerical analyses plays an increasingly important role in research on climate variability and change (e.g., Kalnay et al. 1996). Section 2 provides an overview of the NCEP Global Data Assimilation System (GDAS) and the operational global spectral model. A discussion is also given of the prevailing conditions during the FROST July 1994 SOP, the subject of this paper. In section 3, an evaluation of the analyses is given in comparison to climatology and station observations. The analyses serve as the initial conditions of the model run and are important for assessing the skill of the resulting forecast. Section 4 provides the important results of the forecast evaluation, and a summary is given in section 5 .

\section{Model description and approach}

The NCEP operational global spectral model is run for the production of several forecast products including the medium-range forecast, the aviation forecast, and parallel ensemble forecasts produced from initial condition perturbations. The model has a T126 (triangular truncation) horizontal resolution, which is approximately equivalent to $1^{\circ} \times 1^{\circ}$ resolution, and 28 sigma levels. The 7-day forecasts examined here are run daily at 0000 UTC. A significant obstacle to evaluation of the operational model is that it is routinely modified based on a variety of research efforts and operational considerations. The FROST project encompasses the performance of models at several operational centers; it was not possible to devise SOPs to accommodate periodic changes to all models examined. Significant changes to the NCEP model occurred during the summer FROST SOP on 10 January 1995 that likely influenced highlatitude performance, including modifications to sea ice albedo, atmospheric boundary layer, and cloud parameterizations. Consequently, the evaluation conducted here focuses on the July 1994 SOP. During this time period the model's boundary layer parameterization was largely taken from the GFDL Manual of the E-Physics (Miyakoda and Sirutis 1981). Model cloudiness is primarily diagnosed from the large-scale relative humidity field (Campana et al. 1994). High, middle, and low cloud regimes are defined by the model's sigma layers. A detailed discussion of the NCEP model parameterizations is given by Kanamitsu et al. (1991) and Kalnay et al.

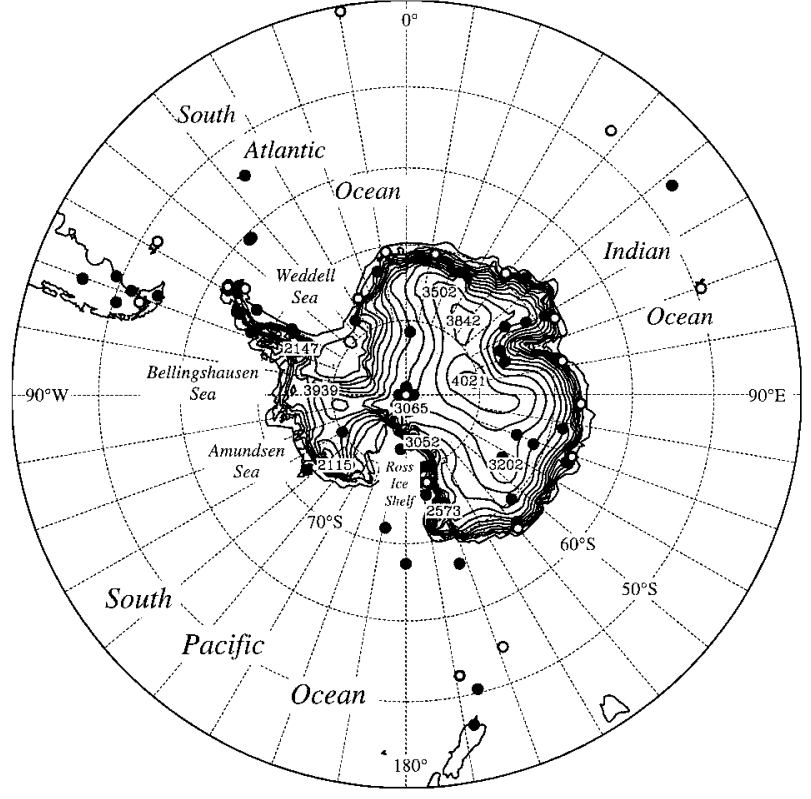

FIG. 1. Map of the Southern Hemisphere poleward of $40^{\circ} \mathrm{S}$ showing the distribution of the surface station network (solid circles) and rawinsonde stations (open circles) in the FROST database, and contours of the Antarctic topography (Drewry 1983) in 300-m increments.

(1996). The NCEP GDAS (Kanamitsu 1989) produces a twice-daily global numerical analysis based on observations reported on the Global Telecommunications System as well as satellite data products from the National Environmental Satellite, Data and Information Service and other sources. A key component of the GDAS system is the use of the operational global spectral model for producing a first-guess field, which supplements the available observations. This is particularly important for the Southern Hemisphere where the sparse data network results in a greater reliance on this modeloutput field.

Figure 1 shows the geographical position of the Antarctic continent in the Southern Hemisphere with reporting stations. The high southern latitudes are a datasparse region, but not a data void. In recent years a decline in the total number of manned stations for the Antarctic continent has been offset by an increase in the introduction of automatic weather stations (AWSes; Stearns et al. 1993) by the U.S. Antarctic Program and other nations. The station distribution is actually quite dense near the Antarctic Peninsula. This is particularly true of surrounding islands (e.g., King George Island). Most of the upper-air network (open circles) is confined to the perimeter of East Antarctica and the Antarctic Peninsula, with only three stations poleward of $75^{\circ} \mathrm{S}$, at South Pole, McMurdo $\left(78^{\circ} \mathrm{S}, 167^{\circ} \mathrm{E}\right)$, and Halley $\left(76^{\circ} \mathrm{S}\right.$, $\left.27^{\circ} \mathrm{W}\right)$. Over the Southern Ocean stations are confined to island locations that are not uniformly distributed. The largest data gap created by this distribution is in the South Pacific. Some drifting buoy data are available 


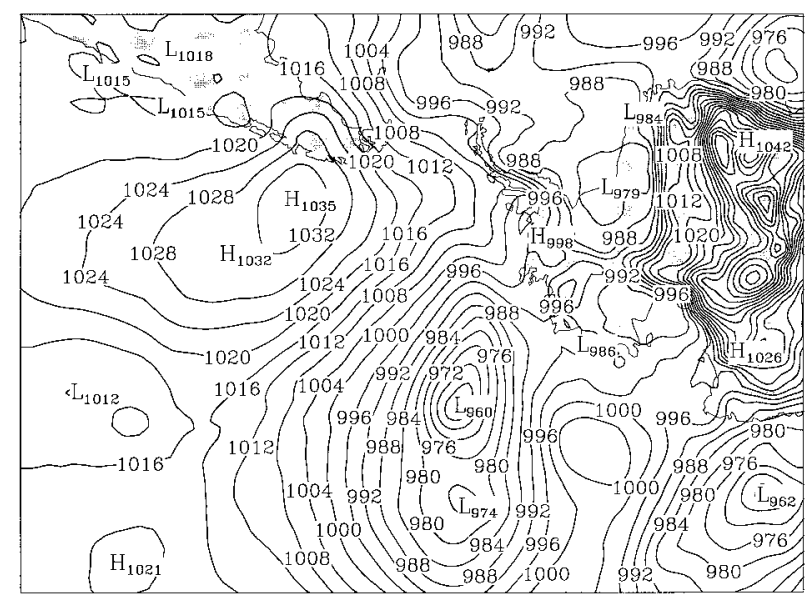

FIG. 2. Mean sea level pressure analysis of the South Pacific Ocean and Drake Passage from NCEP analyses valid 0000 UTC 6 Jul 1994 showing a persistent anticyclone $(1035 \mathrm{hPa})$ near $50^{\circ} \mathrm{S}, 80^{\circ} \mathrm{W}$. The contour interval is $4 \mathrm{hPa}$.

in the western Ross and Weddell Seas. Additionally, Turner et al. (1996) provides an overview of current satellite instruments and their ability to retrieve geophysical parameters over the ocean areas. In addition to these data sources, long-term averaged climatologies of specific variables have been produced for the Antarctic and the Southern Hemisphere. These climatologies, as well as discrepancies between analyses data from NCEP and the European Centre for Medium-Range Weather Forecasts (ECMWF) were found to be the most useful in identifying problems with analyses and forecasts. The ECMWF analyses used are obtained from the Tropical Ocean-Global Atmosphere Archive II, which is available twice daily at a resolution of $2.5^{\circ} \times 2.5^{\circ}$ at nearsurface and 15 standard pressure levels.

Conditions over the continental interior of Antarctica during the July SOP are dominated by the high-constancy katabatic wind flow (Parish and Bromwich 1991) and the highly stable boundary layer inversion. A review of circulation conditions over the remainder of the Southern Hemisphere during the FROST SOPs is given by Beard (1995). A warm Pacific (El Niño) episode gradually intensified during the 1994 austral winter and spring, and peaked during early summer 1994-95. The July 1994 SOP is characterized by a series of strong blocking events in the central and eastern Pacific with an intense block near South America in early July (Fig. 2). The observed Pacific sector anticyclonic events are typical of a warm event in the Southern Oscillation (e.g., van Loon and Shea 1987). These lower-latitude blocking events tend to create distortions in the circumpolar trough. Figure 2, from NCEP analyses for 0000 UTC 6 July, shows a high pressure area near the Pacific coast of South America that persists for about 5 days. Highlatitude Pacific cyclones, such as the $960-\mathrm{hPa}$ center shown, tend to be steered into the Bellingshausen Sea region, rather than continuing through the Drake Pas- sage. This is a condition of interest, as Northern Hemisphere studies have shown that blocking events produce conditions that result in lower quality numerical weather prediction (e.g., Tibaldi and Molteni 1990). Additionally the quality of forecasts during blocking conditions has been found to be related to low model resolution, which results in a feedback loop between regional and planetary scales (Tracton 1990). In the Southern Hemisphere, however, the sparse observational data coverage over the Southern Ocean has been previously shown to be a significant obstacle to the prediction of blocking events (Tibaldi et al. 1994).

\section{Initial-hour comparisons with observations and climatologies}

A comprehensive examination of NCEP analyses for Antarctica has been previously conducted for the years 1985-94 (Cullather et al. 1997). This comparison found significant errors in $200-\mathrm{hPa}$ geopotential heights for central plateau stations prior to May 1986, while surface pressure values showed a general trend toward improvement for the years 1985-90 (see also Trenberth and Olson 1988). Below, the results for the FROST SOP are evaluated in the context of this previous study.

The accurate modeling of Antarctic winter conditions, including the near-surface katabatic winds, is heavily dependent on the accuracy of the model terrain data. As is the case with numerous other atmospheric models, however, the NCEP analyses and forecasts are produced using a dated U.S. Navy elevation dataset, which has been found to contain errors greater than $1 \mathrm{~km}$ in the vertical (e.g., Genthon and Braun 1995). Figure 3 shows the difference of the NCEP topography minus an accepted digital elevation dataset for the Antarctic (Drewry 1983). The largest differences occur in the Queen Maud Land region. Figure 3 is very similar to the Genthon and Braun (1995, see their Fig. 3) comparison for the ECMWF model. This produces some dramatic differences between analyses and AWS observations. Figure 4 shows the average difference in surface pressure values for the July SOP. Not surprisingly, the largest differences of up to $170 \mathrm{hPa}$ occur in areas of steep topography along the Transantarctic Mountains. The exception to this is for the U.S. Automatic Geophysical Observatory station $\mathrm{A} 81\left(82^{\circ} \mathrm{S}, 4^{\circ} \mathrm{E}\right)$, which is located near the large topographic errors in Queen Maud Land. Here, the analysis surface pressure is almost $170 \mathrm{hPa}$ too low. These topographic errors result in discrepancies in the surface temperature distribution (Fig. 5). An incongruity in the $-50^{\circ} \mathrm{C}$ contour is evident near the prime meridian. Two areas of coldest temperatures over the high plateau are consistent with an annual mean temperature synthesis by Radok et al. (1987). The locations of these minimum temperatures do not correspond to the ice sheet topography; rather, they are strongly affected by the overlying model cloudiness, which is discussed in section 4 . It should be noted that a more recent 


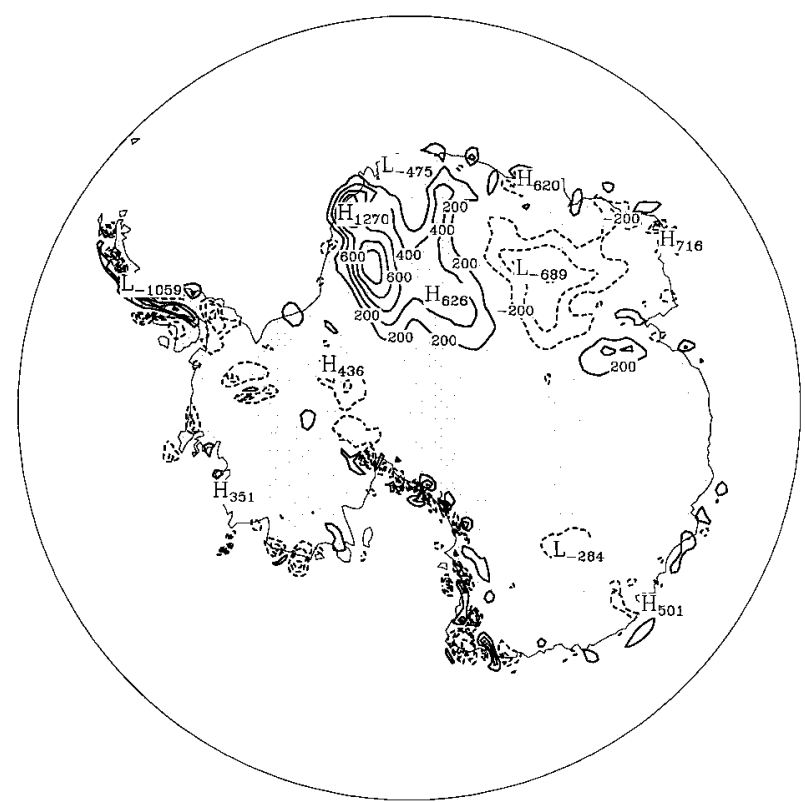

FIG. 3. Difference of the NCEP operational model topography minus the Drewry (1983) elevation dataset, plotted for the region $60^{\circ} \mathrm{S}-$ South Pole. The contour interval is $200 \mathrm{~m}$, and negative contours are dashed.

annual mean synthesis of surface temperatures (Giovinetto et al. 1990) does not resolve a double "pole of cold" on the East Antarctic plateau.

A feature of interest in Antarctic meteorology is the strong near-surface temperature inversion. A climatology of the inversion has been produced by Phillpot and Zillman (1970) and is shown in Fig. 6a. More recently, Connolley (1996) has examined the winter inversion strength using radiosonde measurements and model results in comparison to previous studies. Connolley (1996) concluded that the surface inversion is slightly stronger than that presented by Phillpot and Zillman (1970), although the latter may be preferred for comparison because it is more physically based than other methods. Figure $6 \mathrm{~b}$ shows the NCEP analysis inversion strength, approximated as the difference of the temperature $1000 \mathrm{~m}$ above the surface that has been extrapolated from the analyses' free-atmosphere levels, minus the surface temperature. The Phillpot and Zillman plot is based on the difference of summer and winter surface air temperatures as a predictor of inversion strength. Thus the method for computing the inversion strength from the numercial data is not the same as is used by Phillpot and Zillman (1970), although the latter has been found suitable for validation purposes (e.g., Tzeng et al. 1994). The use of the snow surface temperature in the analysis computation will result in a slight overestimate of the analysis inversion strength. For comparison, Fig. $6 c$ shows the computed ECMWF analysis inversion strength over the same period. In the embayments, the Phillpot and Zillman climatology depicts relatively weak inversion strengths. Both analyses show a near

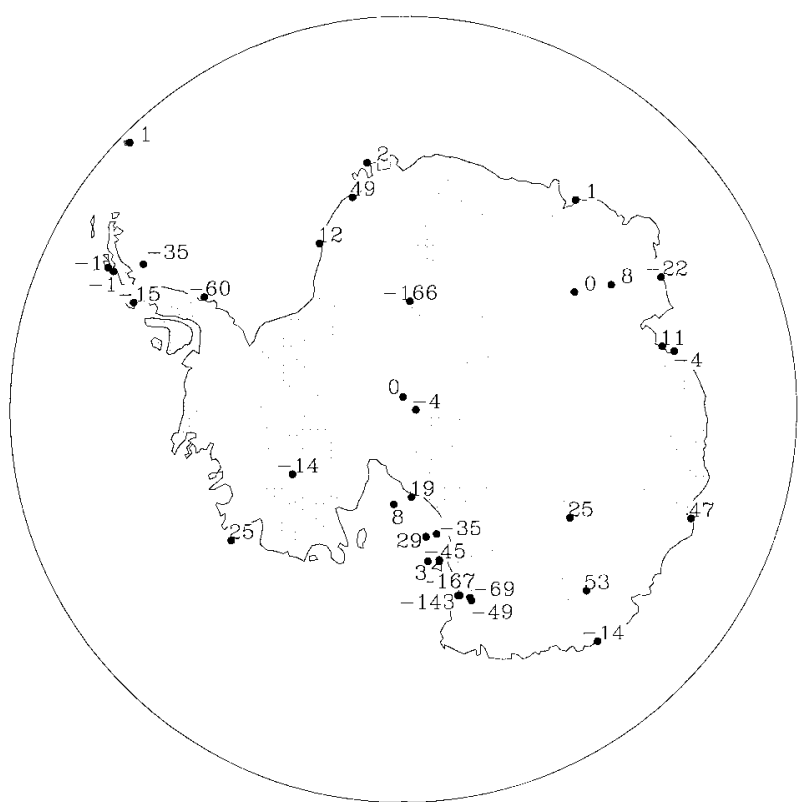

FIG. 4. Average difference of NCEP operational analyses surface pressure minus station observations for July 1994 for the Antarctic continent, in $\mathrm{hPa}$.

absence of an inversion in these regions however, which may result from the numerical weather prediction models' parameterization of the ice shelves as sea ice. Over the interior plateau the ECMWF values are somewhat stronger than the observed magnitude, while the NCEP analyses are clearly weaker than expected. NCEP analyses show values less than $10^{\circ} \mathrm{C}$ over most of the ice

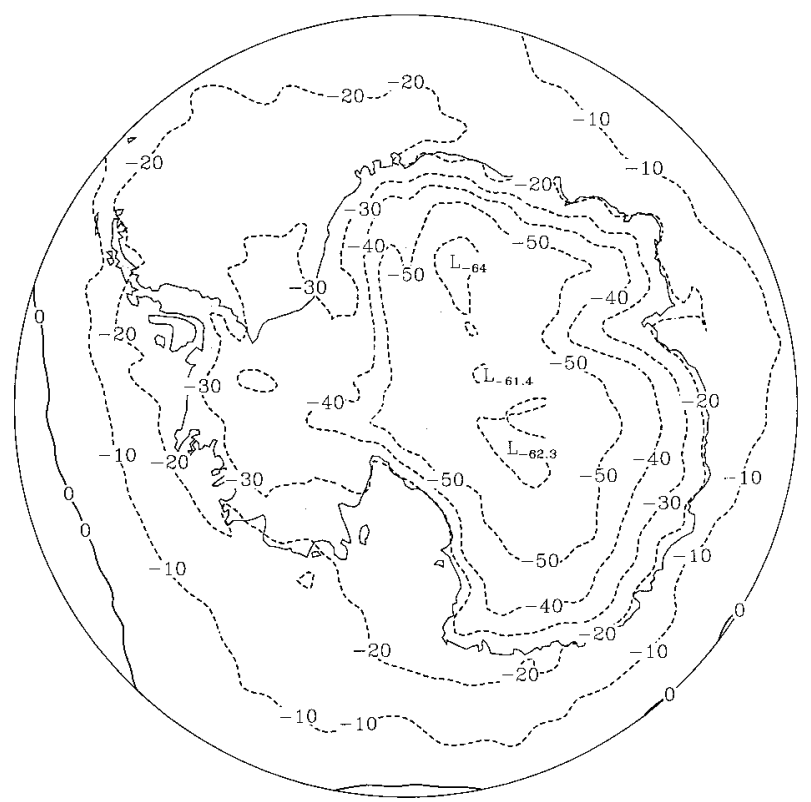

FIG. 5. Average NCEP operational analyses surface temperature for Jul 1994, plotted for the region $60^{\circ} \mathrm{S}-$ South Pole. The contour interval is $10^{\circ} \mathrm{C}$. 


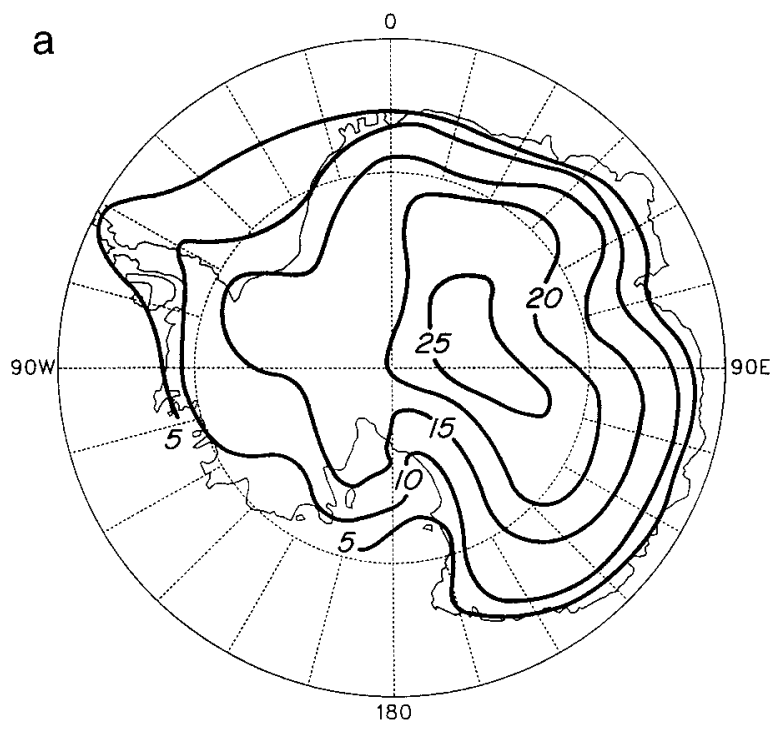

b
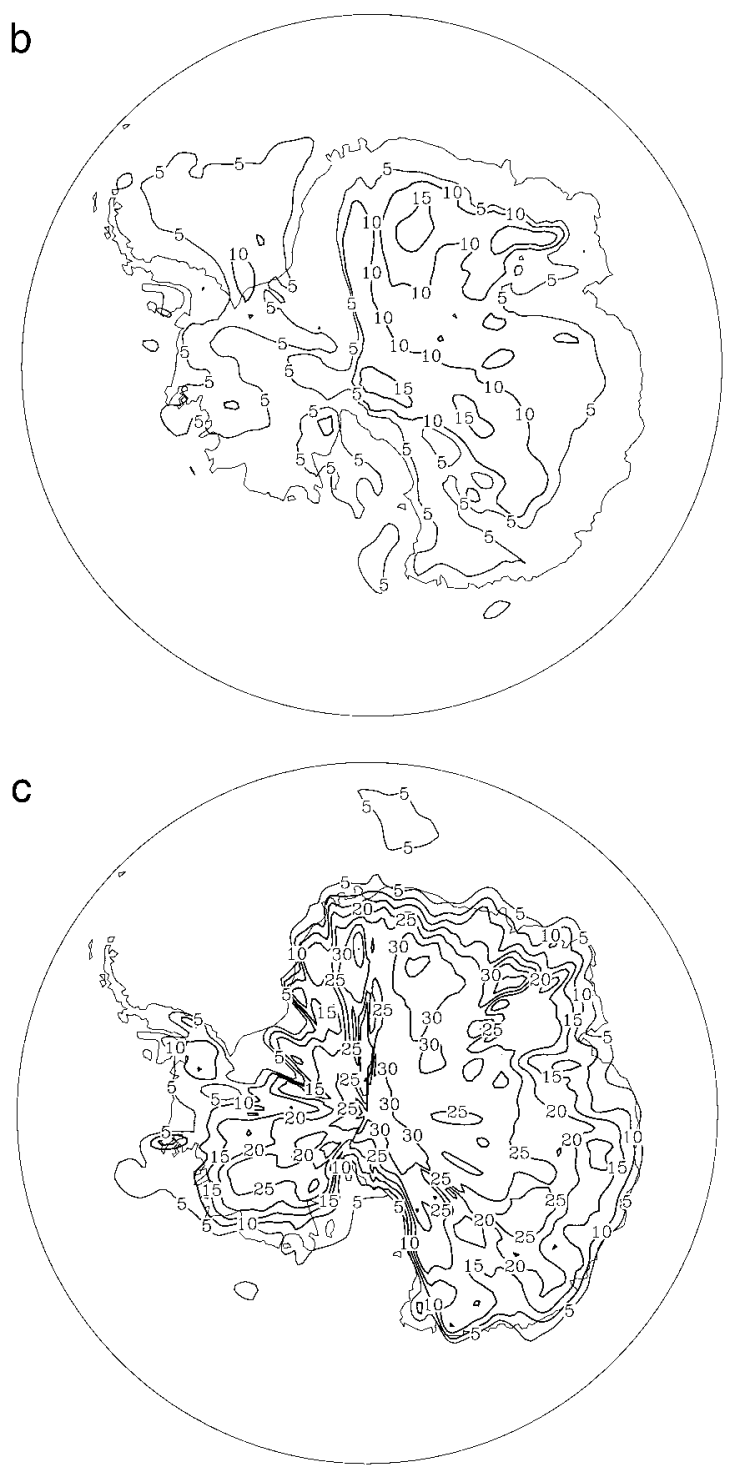

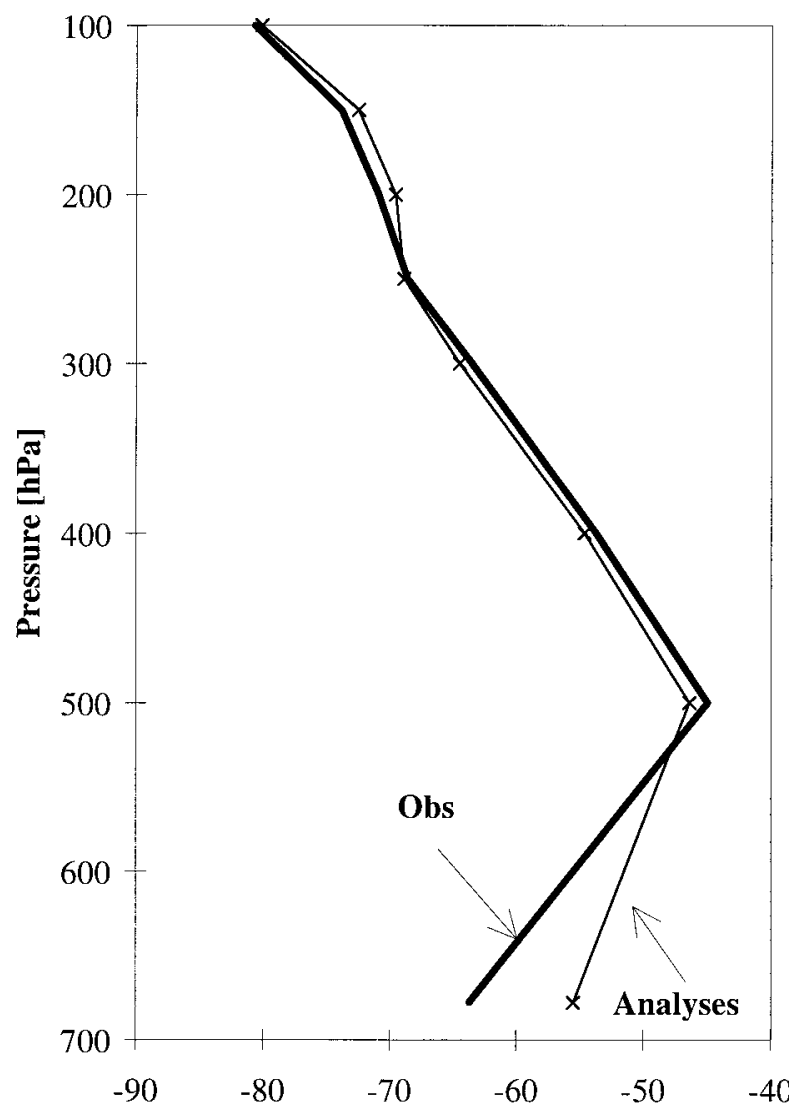

Temperature $\left[{ }^{\circ} \mathrm{C}\right]$

Fig. 7. Average vertical temperature profile from rawinsonde data and NCEP operational analyses at Amundsen-Scott Station $\left(90^{\circ} \mathrm{S}\right)$ for Jul 1994.

sheet, with maximum values less than $20^{\circ} \mathrm{C}$, while the Phillpot and Zillman analysis shows a maximum inversion strength of greater than $25^{\circ} \mathrm{C}$, and corresponding ECMWF analyses show areas greater than $30^{\circ} \mathrm{C}$. Similar to the surface temperature field, two separate areas of maximum values are found for the NCEP East Antarctic inversion. In Fig. 7, the average July 1994 vertical temperature profile from NCEP is compared with rawinsonde data at South Pole. Surface pressure values are within $5 \mathrm{hPa}$ of observation at this station. Analysis

FIG. 6. (a) Synthesis of the observed Antarctic winter near-surface temperature inversion strength (warmest tropospheric temperature minus near-surface air temperature) based on Phillpot and Zillman (1970) and reproduced from Bromwich and Parish (1998). (b) The average temperature inversion strength from NCEP operational analyses, approximated as the free atmosphere temperature $1000 \mathrm{~m}$ above the surface minus the surface temperature, plotted for the region $60^{\circ} \mathrm{S}-$ South Pole for Jul 1994. (c) The average temperature inversion strength from ECMWF operational analyses for Jul 1994. The contour interval for (a)-(c) is $5^{\circ} \mathrm{C}$. 
a.)

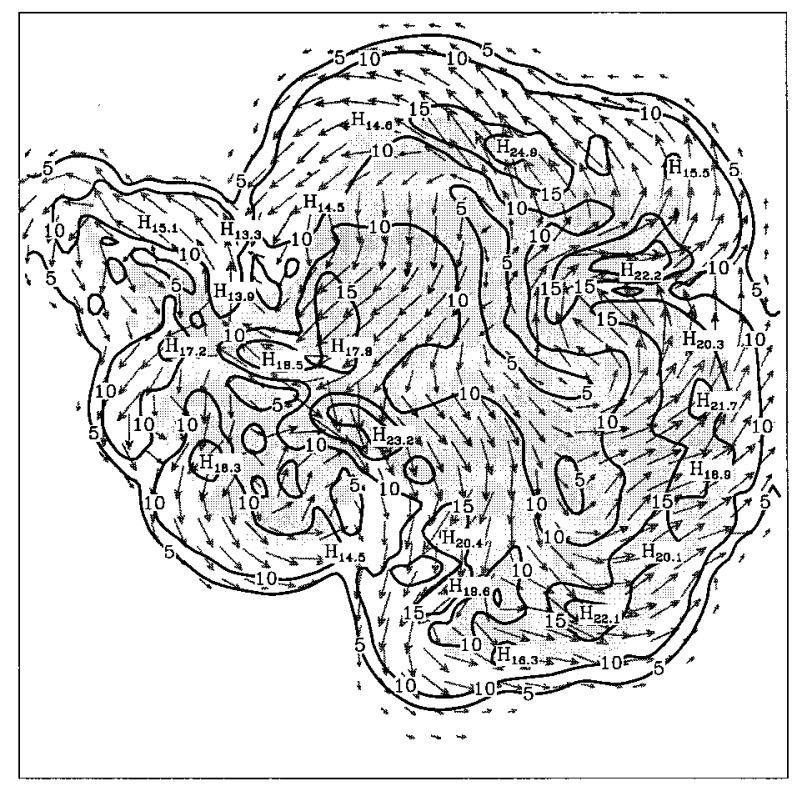

b.)

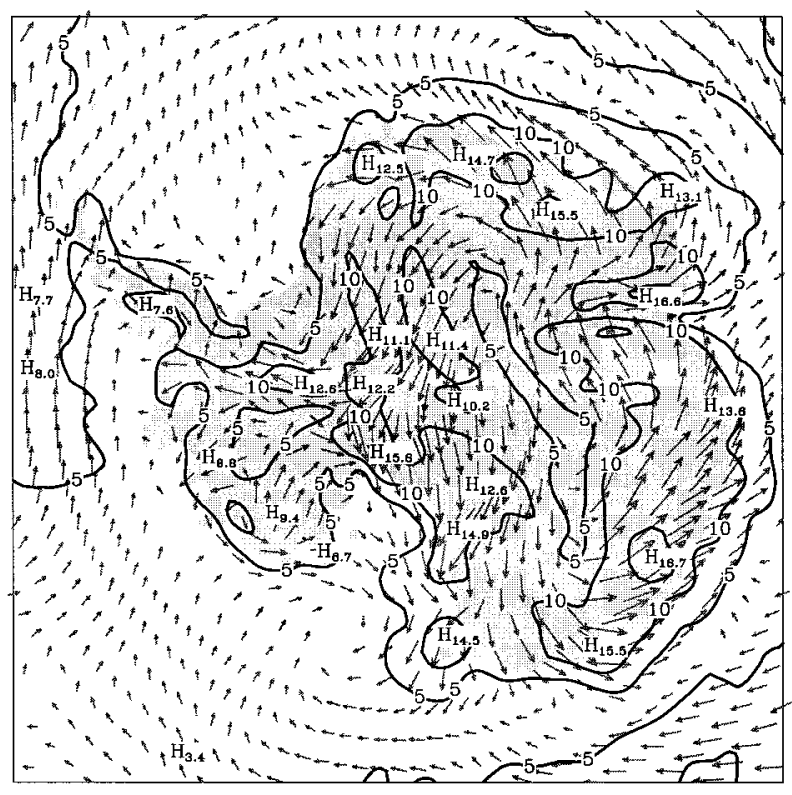

FIG. 8. (a) Simulated Antarctic winter near-surface wind field from Parish and Bromwich (1991). (b) Vector-average near-surface wind field from NCEP analyses for July 1994. The vector-averaged magnitude is contoured every $5 \mathrm{~m} \mathrm{~s}^{-1}$.

values at the surface contain the largest discrepancy with observation. The analysis surface temperature at South Pole is about $7^{\circ} \mathrm{C}$ too warm, significantly reducing the strength of the inversion.

An important outcome from the inversion strength comparison, and one that could be readily addressed, is the incorrect parameterization of the permanent ice shelves as sea ice. This problem has recently been reviewed by Marsiat and Bamber (1997), who examined the sensitivity of a general circulation model (GCM) to the Antarctic land-sea mask. Representing the ice shelves as glaciated land surfaces rather than sea ice resulted in a substantial improvement in the GCM simulation. In the NCEP model, the land parameterization would reduce the ice shelf upward sensible heat flux currently generated by the relatively warm underlying sea surface, resulting in an improved representation of the winter inversion strength and surface temperatures.

In Fig. 8a, an idealized simulation of the near-surface katabatic wind field by Parish and Bromwich (1991) using a high-resolution mesoscale model is shown. Cullather et al. (1997) noted that the NCEP analysis lacked southerly barrier winds along the eastern side of the Antarctic Peninsula. Additionally ECMWF and NCEP analysis speeds were found to be considerably weaker, in part resulting from higher resolution and a better topographic treatment utilized in the mesoscale model (e.g., Tzeng et al. 1994). Lower katabatic wind speeds in the NCEP analyses are also consistent with a weaker inversion. Figure $8 \mathrm{~b}$ shows the average near-surface wind flow for the July SOP from NCEP analyses. The analyses are plotted from $1^{\circ} \times 1^{\circ}$ resolution data with a reduced number of vectors to avoid overlap. Again, a difference in vector-averaged magnitudes for East Antarctic coastal maxima is apparent from the two methods. The highest values in the NCEP analyses are greater than $16 \mathrm{~m} \mathrm{~s}^{-1}$ and occur in Wilkes Land, while the Parish and Bromwich model shows corresponding values of greater than $20 \mathrm{~m} \mathrm{~s}^{-1}$, with the largest values in Queen Maud Land of greater than $24 \mathrm{~m} \mathrm{~s}^{-1}$. At high resolution a weak representation of southerly barrier winds along the Antarctic Peninsula is apparent in the NCEP analyses; however, the magnitude is about $5 \mathrm{~m} \mathrm{~s}^{-1}$, in comparison to the Parish and Bromwich depiction, which shows values of up to $15 \mathrm{~m} \mathrm{~s}^{-1}$ in this area. Despite the magnitude differences, the vector directions are in reasonable agreement for all of East Antarctica, particularly for South Pole and along Shackleton Coast, west of the Ross Ice Shelf. Over West Antarctica there is more substantial disagreement in the vector-averaged wind directions (Turner et al. 1996). This may be due in part to the South Pacific blocking conditions present during the July SOP, which are not present in the mesoscale model.

Comparisons with rawinsonde data during the FROST SOP are similar to those examined in Cullather et al. (1997), which indicate that, in general, most of the available observational data is being included into the analyses. This is particularly true of the sparse Southern Ocean island stations. Figure 9 shows an ex- 


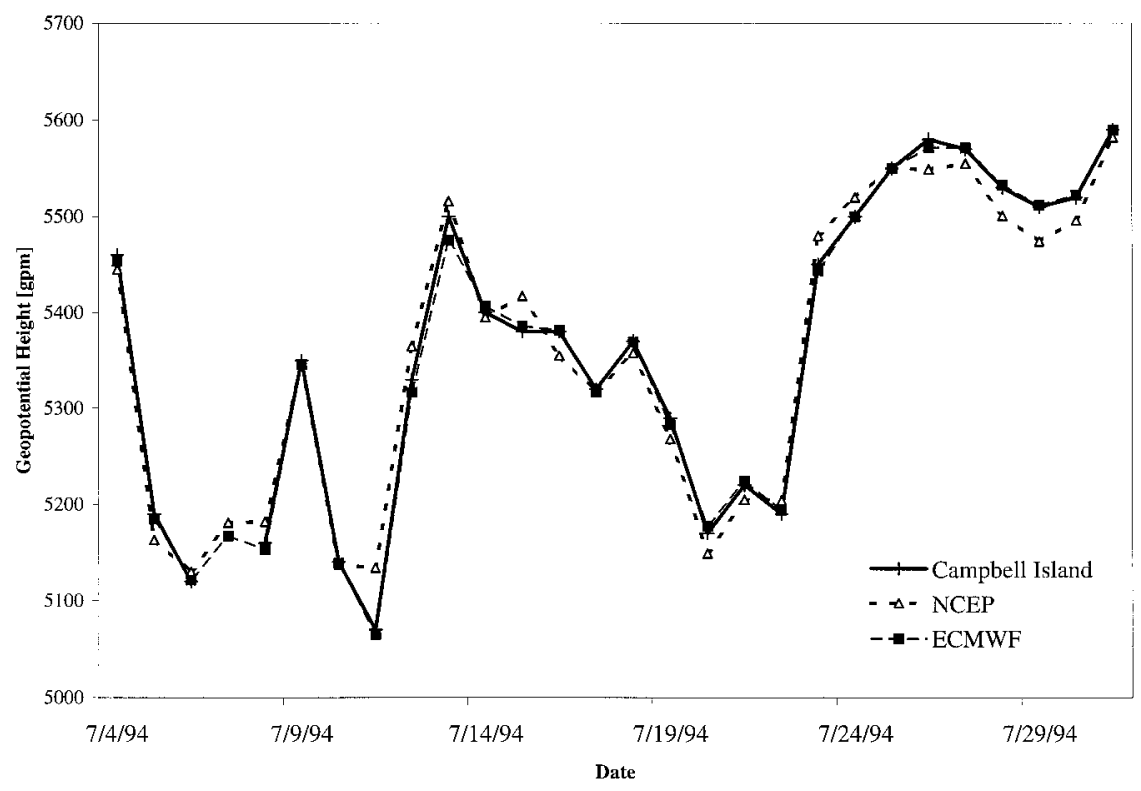

FIG. 9. Time series of 500-hPa geopotential height from rawinsonde observation, NCEP analyses, and ECMWF analyses at Campbell Island $\left(53^{\circ} \mathrm{S}, 169^{\circ} \mathrm{E}\right)$ for Jul 1994.

ample of this for Campbell Island $\left(53^{\circ} \mathrm{S}, 169^{\circ} \mathrm{E}\right) 500-$ $\mathrm{hPa}$ geopotential heights. The average NCEP value is low for this station by only $7 \mathrm{gpm}$. Over the month, the correlation with observation for NCEP is close to unity $\left(r^{2}=0.98\right)$ while corresponding values from the ECMWF are marginally superior in both correlation $\left(r^{2}\right.$ $=0.99)$ and root-mean-square $(\mathrm{rms})$ sense $(6.9 \mathrm{gpm}$ versus $24.3 \mathrm{gpm}$ for NCEP). Macquarie Island $\left(55^{\circ} \mathrm{S}\right.$, $\left.159^{\circ} \mathrm{E}\right)$, Marion Island $\left(47^{\circ} \mathrm{S}, 38^{\circ} \mathrm{E}\right)$, and other stations compare similarly. Over the Antarctic continent, the monthly mean values begin to show discrepancies. Figure 10 shows values for South Pole. Although the correlation for the NCEP analysis with observation is still high due to the large variability, it is apparent that data have either been eliminated as a result of quality control, or have not been received by the analysis centers. NCEP values show a substantial bias in comparison to observation of $-47 \mathrm{gpm}$. By comparison the ECMWF analyses show a smaller difference of $-14 \mathrm{gpm}$. A similar $-44 \mathrm{gpm}$ bias is also found for NCEP analyses at McMurdo $\left(78^{\circ} \mathrm{S}, 167^{\circ} \mathrm{E}\right)$.

\section{Forecast comparisons}

An examination of a suite of NCEP medium-range forecasts for July 1994 indicates a substantial amount of adjustment occurs in the numerical model during the first $36 \mathrm{~h}$ of an average forecast. Some fields, however, continue to drift after this period. As will be shown below, the majority of this adjustment occurs over the Antarctic continent. Over the Southern Ocean, the most significant model adjustment is in the circumpolar trough, which moves equatorward from $63.3^{\circ}$ to $61.4^{\circ} \mathrm{S}$ over the 7-day forecast period. For comparison the
ECMWF analyses show the average July 1994 trough position near $65^{\circ} \mathrm{S}$. Figure 11 a shows the significant magnitude of these adjustments in the zonally averaged surface pressure changes. The plot implies a shift in atmospheric loading from middle to higher latitudes with forecast hour. Although most of the adjustment is concluded by forecast hour 72, it is apparent that this shift continues through day 7 of the forecast. Recent sensitivity studies using climate models have examined the impact of various factors, including cloud parameterizations (e.g., Lubin et al. 1998), on the latitudinal position of the circumpolar trough in atmospheric models. In Lubin et al. (1998), a scenario that has been found to result in an equatorward shift of the circumpolar trough is associated with tropospheric warming above the continental inversion, resulting in pressure rises over Antarctica and subsequent pressure falls farther to the north. The resulting model trough weakens and moves equatorward. The temperature field over the Antarctic continent and pressure changes in the NCEP model are consistent with this synopsis. Additionally, part of the reason for this shift lies with the model's inability to predict specific blocking patterns at middle latitudes over the latter part of the forecasting period. The spatial distribution of these pressure changes is shown in Fig. 11b. Negative values west of the Drake Passage are associated with an extended blocking pattern not captured in later forecast hours. The substantial increases in surface pressure surrounding the continent result in a greatly reduced pressure gradient forcing of the katabatic winds. Near-surface wind magnitudes decrease significantly with forecast time.

In Fig. 12, the model 5-day 500-hPa geopotential height differences with analyses are shown. Biases with 


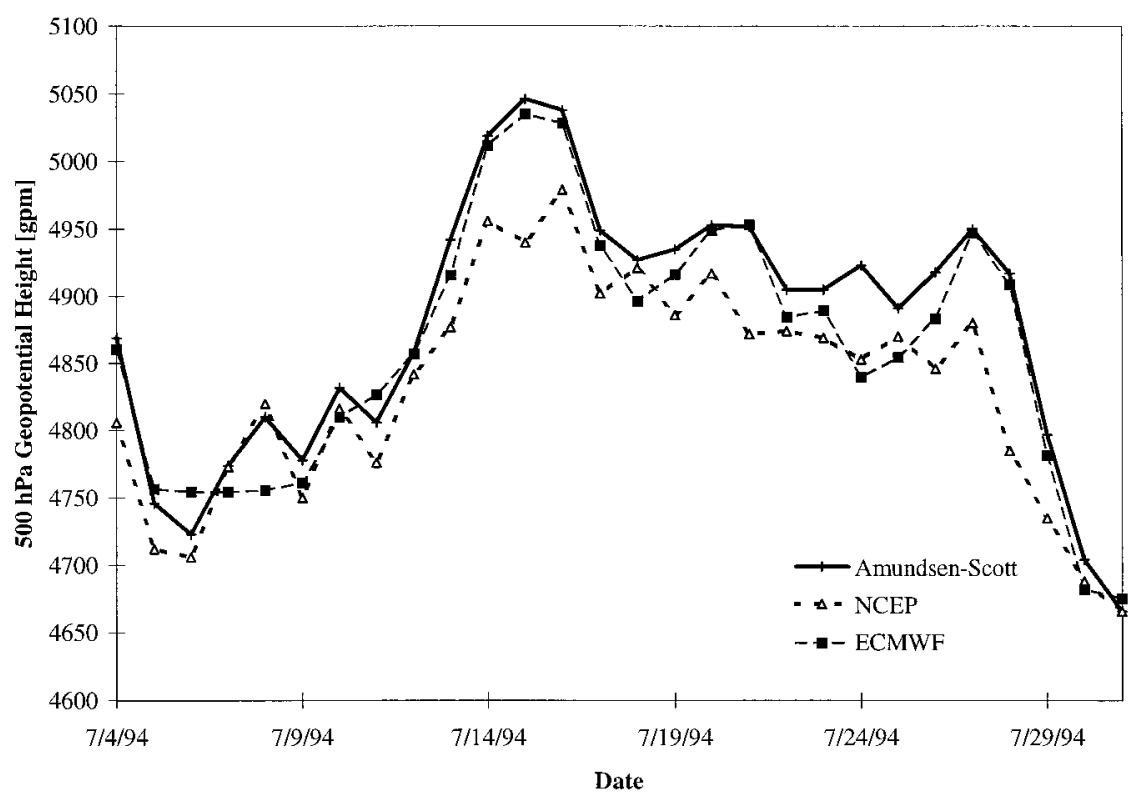

FIG. 10. As in Fig. 9 but for Amundsen-Scott $\left(90^{\circ} \mathrm{S}\right)$.

magnitudes greater than $(-) 60$ gpm are shown to the west of the Drake Passage, which reflect the extended period blocking event shown in Fig. 2. By day 7 this bias has a magnitude of greater than $(-) 115 \mathrm{gpm}$. An examination of forecast values in comparison rawinsonde observations finds that rms errors generally grow faster for Southern Ocean stations than for the Antarctic coastal stations. Macquarie Island $\left(55^{\circ} \mathrm{S}, 159^{\circ} \mathrm{E}\right) 500$ $\mathrm{hPa}$ geopotential height rms error increased by $22.4 \mathrm{gpm}$ per forecast day, and similar values are found for Mount Pleasant $\left(52^{\circ} \mathrm{S}, 58^{\circ} \mathrm{W}\right)$ and Campbell Island. This compares with $11.6 \mathrm{gpm}$ per forecast day for Davis $\left(69^{\circ} \mathrm{S}\right.$, $78^{\circ} \mathrm{E}$ ). This is particularly true for the later part of the forecast beyond day 3. The average rms error growth rate for Southern Ocean stations for forecast days 4-7 is more than twice that of the coastal stations. A major reason for this effect is likely to be the data paucity for the Southern Ocean. Coastal stations are more likely to benefit from other observations made upflow from their position than the island stations. Additionally the wintertime topographically induced circulation over the continent may also provide an additional degree of predictability that is not present over the Southern Ocean. This has been further analyzed by examining the forecast skill scaled by persistence, using

$$
\mathrm{SS}=1-\frac{\mathrm{MSE}(\text { forecast })}{\mathrm{MSE}(\text { persistence })},
$$

where MSE is the mean squared difference with analysis values. Over the Southern Ocean, the zonally averaged skill score for $60^{\circ} \mathrm{S}$ is essentially zero at day 1 and linearly decreases to negative values thereafter. This contrasts with coastal values near $70^{\circ} \mathrm{S}$, which remain positive throughout the forecast.
Figure 12 also indicates some of the larger changes occurring over the Antarctic continent. These changes are characterized by a decrease in $500-\mathrm{hPa}$ geopotential height over the high interior plateau and a large increase over West Antarctica. These changes appear to be largely the result of adjustments to compensate for deficiencies in the initial fields, and particularly in the temperature profile, which likely result from an imbalance in the atmospheric surface energy budget at the beginning of the forecast. A more comprehensive analysis of the energy budget is given by Hines et al. (1999, this issue). It should be noted, for example, that the 500-hPa geopotential height bias at Amundsen-Scott actually improves with forecast hour and is essentially eliminated by day 4 of the average forecast. An area of positive values is also present near the coast of East Antarctica near $100^{\circ} \mathrm{E}$, which appears to result from analysis storms that turn inland in this region. This storm track is not adequately represented in the model forecasts, and the gradient between interior and coastal adjustments in East Antarctica results in a more symmetric forecast height field in the NCEP forecasts. This contrasts with a ridging pattern over Wilkes Land in the 500-hPa NCEP analyses. It should be noted that the spatial gradient of 500-hPa geopotential heights becomes relatively small over Antarctica, in contrast to the sharp meridional gradient over the Southern Ocean. Thus the large adjustments in the geopotential height field over the continent are clearly realized as circulation changes in the 500$\mathrm{hPa}$ wind field over the continent.

Figure 13 defines an area of interest in East Antarctica by the day 5 average forecast bias in $500-\mathrm{hPa}$ temperature. In comparison to the analysis fields the NCEP model temperatures at this level have warmed by as 

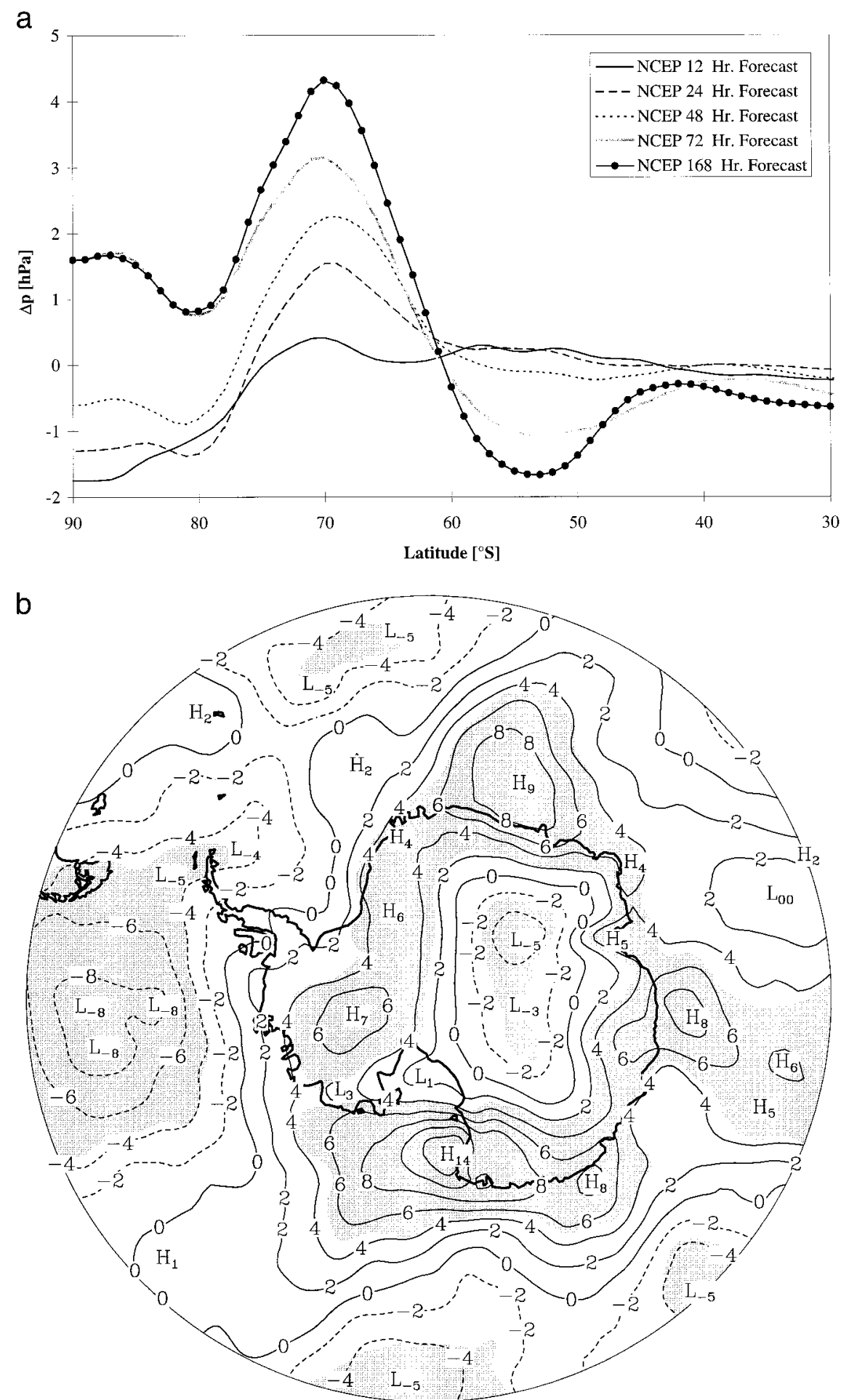

FIG. 11. (a) Zonal average of surface pressure from various NCEP average forecast hours minus NCEP analyses for July 1994. (b) Average NCEP day 5 average forecast surface pressure minus NCEP analyses for July 1994. The contour interval is $2 \mathrm{hPa}$. Shaded areas indicate significance at the $95 \%$ confidence level based on a two-sided Student's $t$-test. 


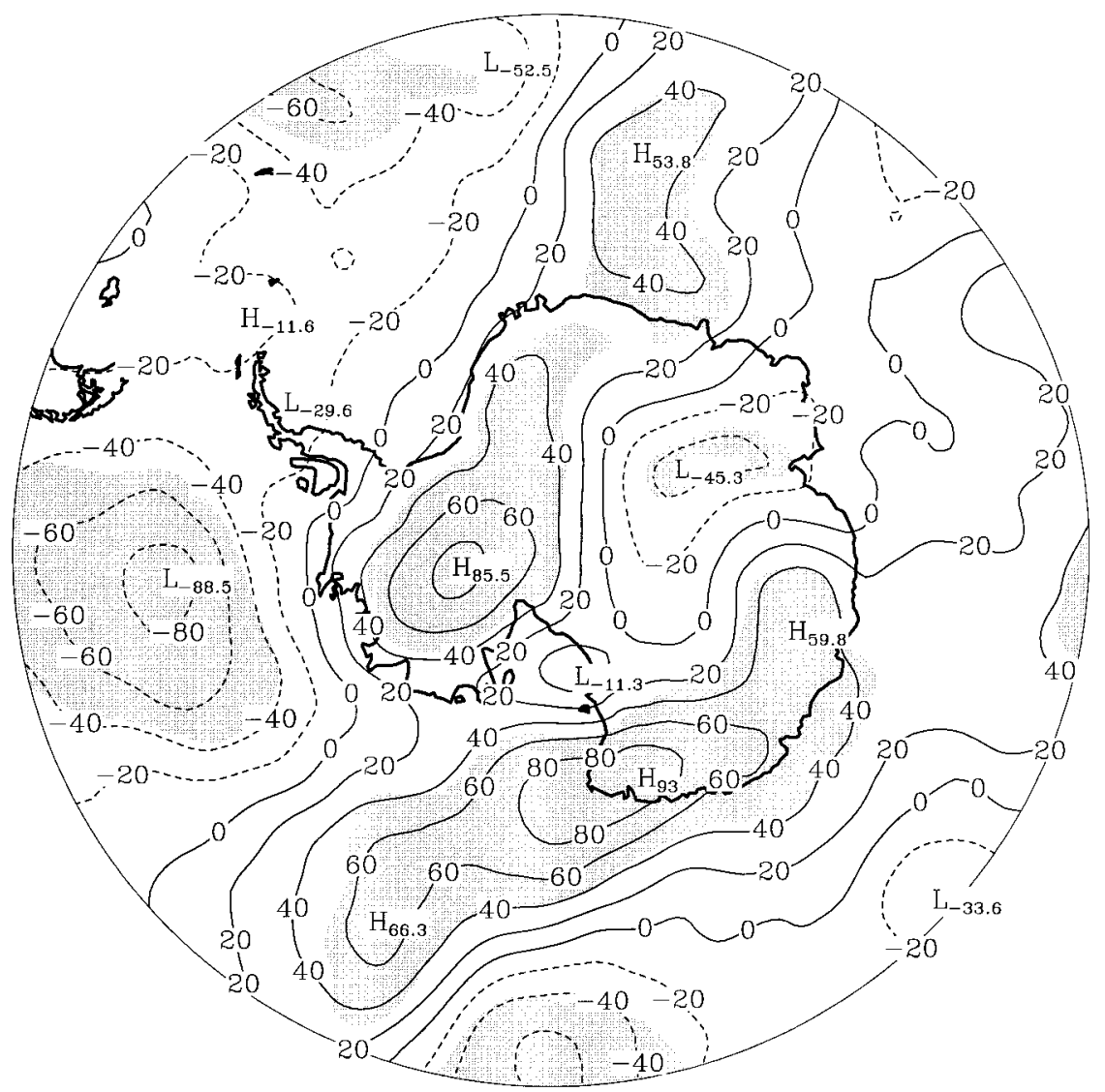

FIG. 12. Average NCEP day 5 average forecast $500 \mathrm{hPa}$ geopotential height minus NCEP analyses, plotted for the region $50^{\circ} \mathrm{S}-$ South Pole for Jul 1994. The contour interval is $20 \mathrm{gpm}$. Shaded areas indicate significance at the $95 \%$ confidence level based on a two-sided Student's $t$-test.

much as $4^{\circ} \mathrm{C}$ over the interior plateau, in a region that appears to be related to topography. This region is surrounded by mostly negative values to about $55^{\circ} \mathrm{S}$. Positive values are again found over middle latitudes. This contrasts with surface temperatures that essentially show opposite trends. As a result, the inversion strength over Antarctica also improves with forecast hour. Figure 14 shows the day 5 average forecast inversion strength. Although the inversion is still deficient in comparison to the Phillpot and Zillman climatology, the $10^{\circ} \mathrm{C}$ contour now covers most of the East Antarctic high plateau with maximum values of greater than $20^{\circ} \mathrm{C}$ centered on Vostok $\left(78^{\circ} \mathrm{S}, 107^{\circ} \mathrm{E}\right)$. With increasing forecast hour the near-surface temperature inversion continues to strengthen past day 5. To indicate this progression, the forecast temperatures at various levels are averaged over the East Antarctic plateau area bounded by the $1^{\circ} \mathrm{C}$ contour in Fig. 13. These temperatures are plotted in Fig. 15. Middle- and upper-tropospheric temperatures for this region increase by between $1^{\circ}$ and $2^{\circ} \mathrm{C}$ during the first 24-36 h and level off. In comparison, surface and lower-stratospheric temperatures cool by $2^{\circ} \mathrm{C}$ over the first 3 days at a constant rate and continue to cool for the duration of the forecast. This creates a contrast between upper-troposphere adjustments and the rest of the atmosphere.

In Fig. 16 the vertical profile of day 5 temperature drift is zonally averaged to yield a depiction for the Southern Hemisphere. The pattern of warming middle troposphere and cooling surface and stratosphere is actually reversed for the surrounding sea ice zone, with cooling in the upper troposphere; there is a suggestion that the pattern reverses yet again for lower latitudes. The temperature drift for the Southern Hemisphere is largest over Antarctica, and there is no corresponding pattern for the Northern Hemisphere. Also shown in Fig. 16 are the vector-average meridional circulation changes. The decrease in the strength of the katabatic winds is indicated by near-surface vectors near $70^{\circ} \mathrm{S}$, which point back toward the continent. In a statically stable atmosphere, one would expect the circulation adjustments to correspond directly to temperature changes, with cooling occurring in the presence of increased rising motion and warming associated with increased subsidence. An example of this may be found in Lubin et al. (1998). In Fig. 16, however, there is no clear relation 


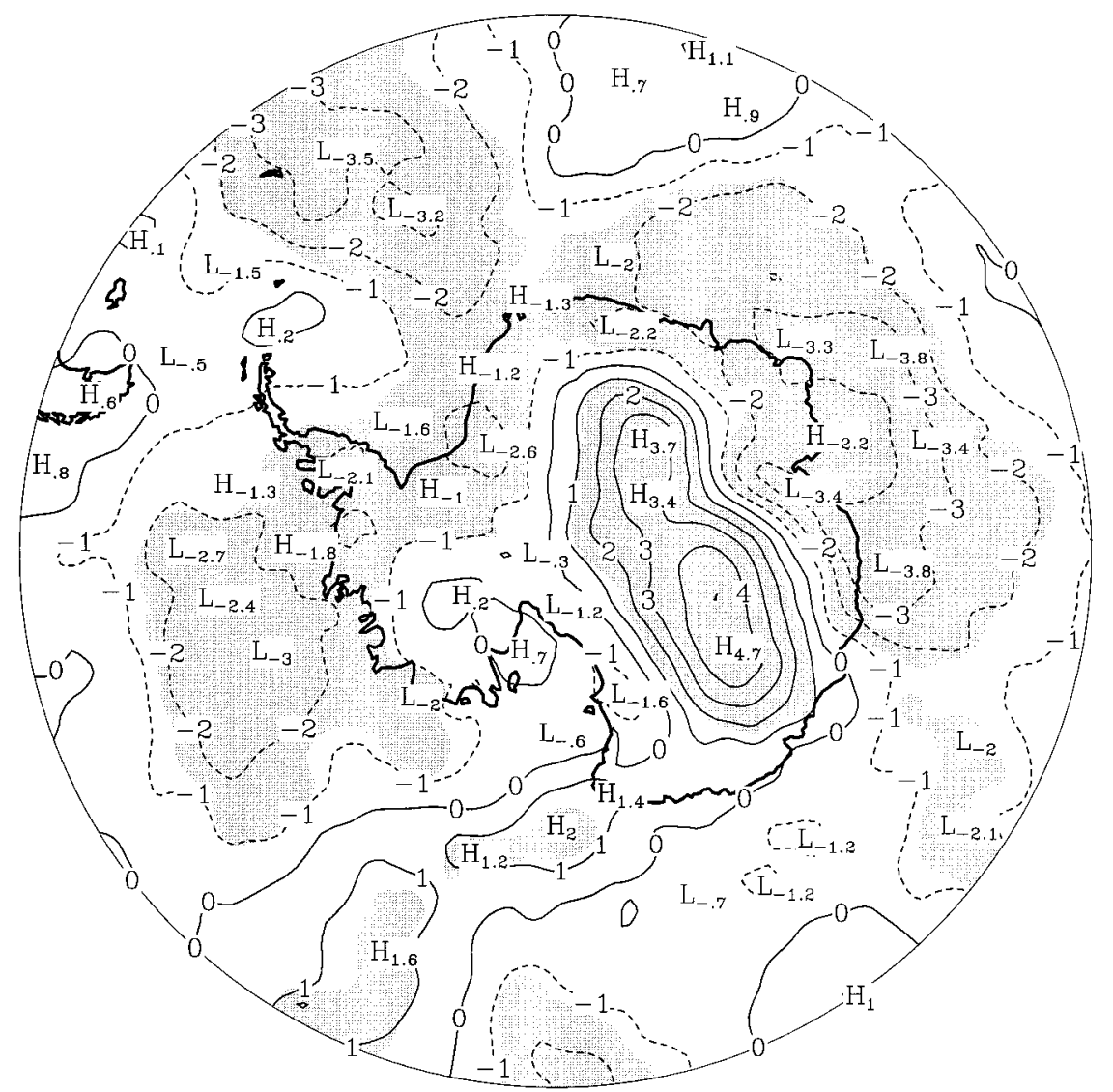

FIG. 13. Average NCEP day 5 average forecast 500 -hPa temperature minus NCEP analyses, plotted for the region $50^{\circ} \mathrm{S}-$ South Pole for Jul 1994. The contour interval is $1^{\circ} \mathrm{C}$. Shaded areas indicate significance at the $95 \%$ confidence level based on a two-sided Student's $t$-test.

between the two fields and therefore no simple answer to the model drift. At high latitudes the circulation changes are in the form of two vertical counterclockwise circulations, with enhanced rising motion near $88^{\circ} \mathrm{S}$, subsidence near $80^{\circ} \mathrm{S}$, rising motion near $72^{\circ} \mathrm{S}$, and subsidence near $60^{\circ} \mathrm{S}$. This pattern and its relation to the temperature departure field is intriguing. The two vertical motion patterns occur in the presence of temperature departures of opposite sign. The effect of these circulation changes is a narrowing of the polar cell. In the analyses, the largest subsidence motion occurs near $88^{\circ} \mathrm{S}$. As the forecast progresses, the latitude of maximum subsidence moves equatorward to near $82^{\circ} \mathrm{S}$, while rising motion over the Southern Ocean moves slightly poleward. The lower-latitude subsidence is probably more realistic as it corresponds to steeper terrain and larger near-surface divergence. Farther north, rising air departures between $40^{\circ}$ and $55^{\circ} \mathrm{S}$ have the effect of enhancing the Ferrel cell circulation.

The drift in the model cloud fraction is consistent with the forecast temperature changes. Over high southern latitudes the model middle cloud fraction is dominant in comparison to the high and low cloud domains. Figure 17 shows the average spatial distribution at fore- cast day 1. Middle cloud fractions of around 50\% surround the perimeter of the East Antarctic escarpment. The interior is dominated by a spurious wave pattern (Cullather et al. 1996), which is found to be present in moisture fields for latitudes from $70^{\circ} \mathrm{S}$ to the South Pole. This pattern has been found to result from an oversimplification of the horizontal diffusion parameterization along constant pressure surfaces (W. M. Ebisuzaki 1996, personal communication). Individual cloud streets contain fractions of up to $70 \%$ but are immediately adjacent to meridionally oriented areas that are essentially cloud free. The drop in middle cloud fraction with forecast hour (Fig. 18) leads to surface radiative cooling that essentially transports heat into the upper troposphere. A possible feedback occurs as the upper troposphere warms, lowering the model relative humidity and further reducing the cloud fraction.

While the average model cloudiness and relative humidity fields become considerably altered with forecast time, there does not appear to be significant change in the atmospheric moisture budget for the Antarctic interior over the forecast. The atmospheric moisture budget may be written as (e.g., Bromwich and Robasky 1993) 


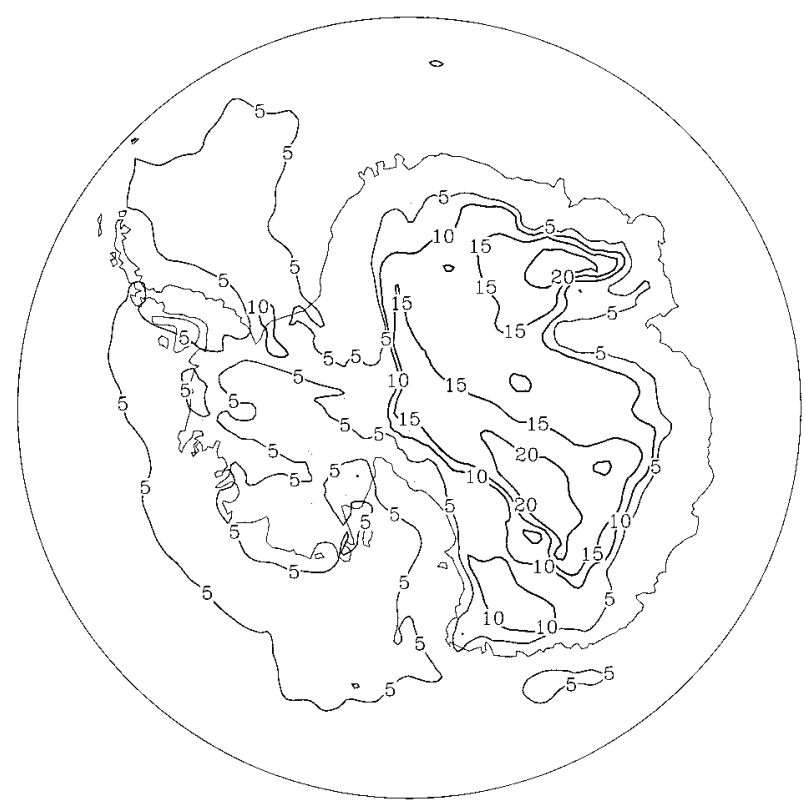

FIG. 14. The average temperature inversion strength from NCEP day 5 average forecasts, defined as the free atmosphere temperature $1000 \mathrm{~m}$ above the surface minus the surface temperature, plotted for the region $60^{\circ} \mathrm{S}-$ South Pole for Jul 1994 . The contour interval is $5^{\circ} \mathrm{C}$.

$$
P-E=-\frac{\partial W}{\partial t}-\nabla \cdot \frac{1}{g} \int_{P_{\text {top }}}^{P_{\text {stc }}} q \mathbf{V} d p,
$$

where $W$ is precipitable water, $P_{\text {sfc }}$ is surface pressure, $g$ is the gravity constant, $q$ is specific humidity, and $\mathbf{V}$ is the horizontal wind vector. The variable $P_{\text {top }}$ is the highest level of the atmosphere, which is not zero in the analyses. All variables on the right-hand side are

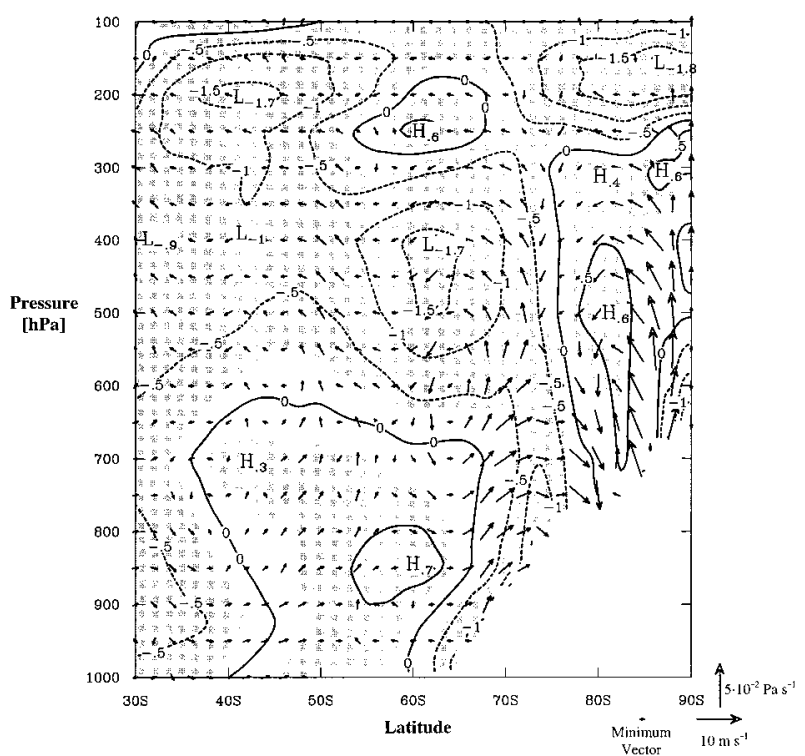

FIG. 16. Zonally averaged vertical profile of NCEP day 5 average forecast temperature minus analysis for July 1994. The contour interval is $0.5^{\circ} \mathrm{C}$. Shaded areas indicate significance at the $95 \%$ confidence level based on a two-sided Student's $t$-test. Vectors indicate the day 5 vector-average forecast meridional and vertical winds minus analysis.

produced for instantaneous times of each forecast including the zero-hour analysis, while precipitation $(P)$ and evaporation/sublimation $(E)$ are model-produced fields that are accumulated over time intervals during the forecast. Thus, for a given forecast, (2) is not explicitly required. Hydrologic balance should be expected over a suite of forecasts, however. The atmospheric

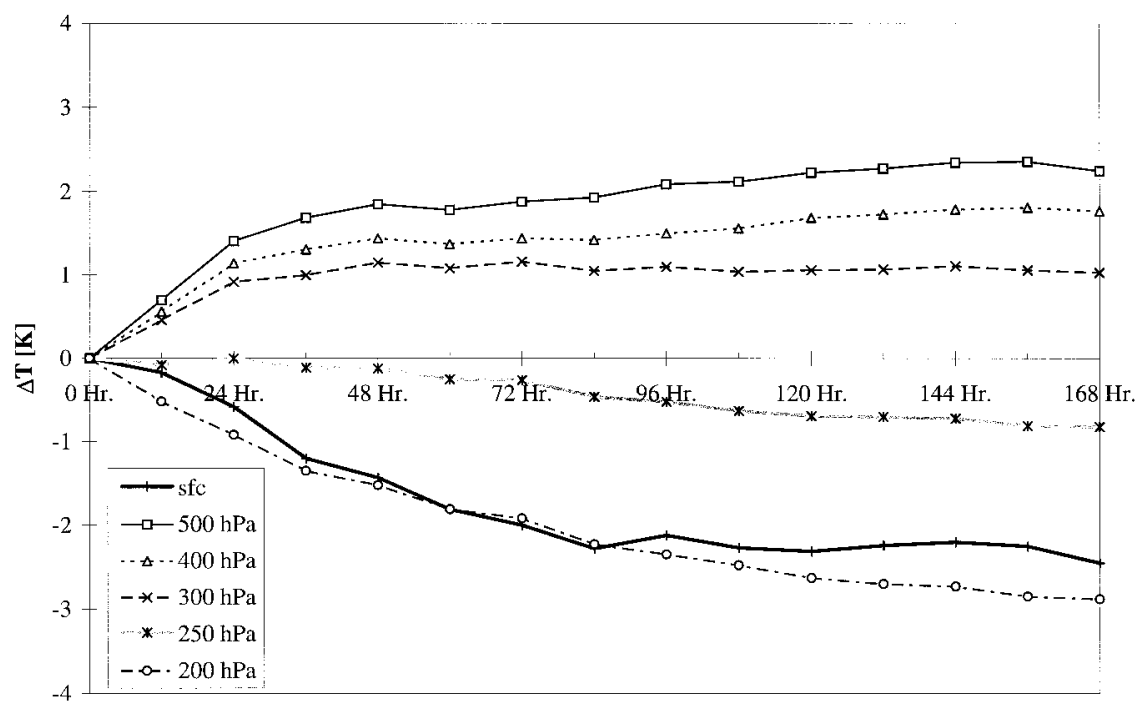

Forecast Hour

FIG. 15. Time series of the departure of NCEP forecast temperatures from analysis values vs forecast hour for various levels of the atmosphere for Jul 1994, averaged over the East Antarctic area defined by the $1^{\circ} \mathrm{C}$ contour in Fig. 13 . 


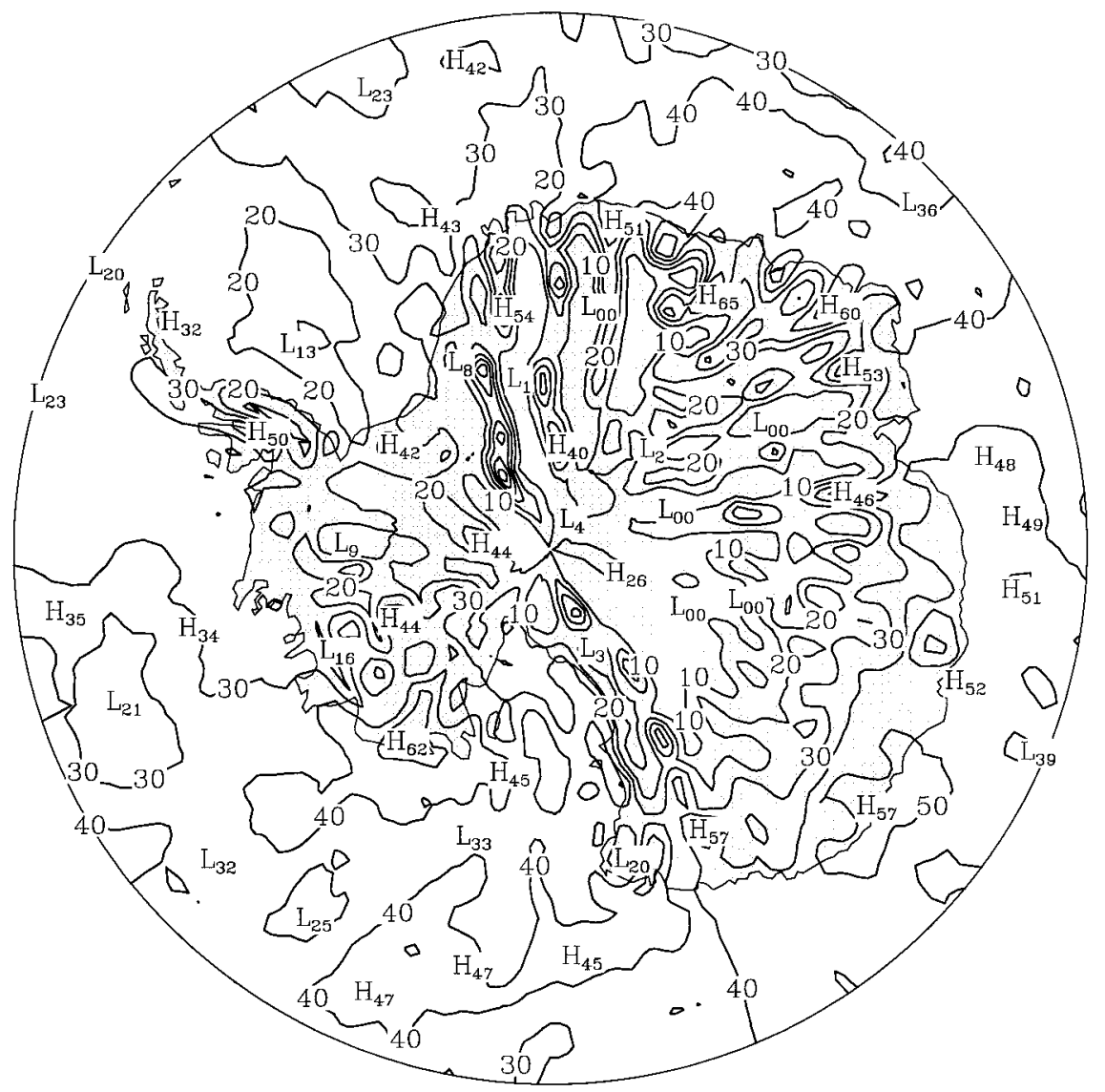

FIG. 17. The average NCEP day 1 average forecast middle cloud coverage, plotted for the region $60^{\circ} \mathrm{S}-$ South Pole for Jul 1994 . The contour interval is $10 \%$.

moisture budget is an integral part of the weather and climate of high southern latitudes, and the components of (2) are of significant climate interest (e.g., Bromwich et al. 1995; Genthon and Braun 1995).

Figure 19 shows the zonally averaged NCEP model atmospheric moisture budget in comparison to forecast $P-E$. For the region $70^{\circ} \mathrm{S}$ to the South Pole, the $P-$ $E$ computed from the zero-hour moisture budget analysis is $12.5 \mathrm{~mm} \mathrm{month}^{-1}$. By day 4 , the moisture budget $P-E$ is $16.1 \mathrm{~mm}$ month $^{-1}$. Most of the difference occurs at the perimeter of the Antarctic continent (Fig. 20). A zonal minimum in the analysis moisture budget $P-E$ near $72^{\circ} \mathrm{S}$ is greatly reduced by day 3 . This is easily seen in Fig. 20, which shows values of greater than $20 \mathrm{~mm} \mathrm{month}^{-1}$ difference between forecast and analysis values near $70^{\circ} \mathrm{S}$. Because the modeled precipitation and evaporation/sublimation values are not instantaneous but accumulated over a 12 -h period, values for the left-hand side of Eq. (2) only roughly correspond in time. These values for model forecast $P-E$ for the area $70^{\circ} \mathrm{S}$ to the South Pole are 20.2 and $17.2 \mathrm{~mm}$ month $^{-1}$ for the $0-0.5$-day field and for the day 3.5-4 forecast, respectively. In comparison with the moisture budget values, however, it is apparent that the model is not in hydrologic balance at the initial period, which agrees with previous findings (e.g., Mo and Higgins 1996). As the forecast progresses, however, the moisture budget residual becomes much closer to the model $P-$ $E$ values. This imbalance reduces from an initial value of $7.7 \mathrm{~mm} \mathrm{month}^{-1}$ to only $1.1 \mathrm{~mm} \mathrm{month}^{-1}$ by day 4 .

\section{Summary}

An analysis of the NCEP operational global spectral model performance over Antarctica and the surrounding sea ice region during the July 1994 special observing period has been conducted. Over the Antarctic continent, substantial adjustment occurs over the first few days of the medium-range forecast in temperature, geopotential height, and cloud cover, while drift continues in several variables beyond this initial period. The atmospheric moisture budget over the region $70^{\circ} \mathrm{S}-$ South Pole adjusts significantly toward hydrologic balance by forecast day 4 . The analysis presented here is not a complete diagnosis of the NCEP model's behavior but rather provides an overview of the detected model tendencies in high southern latitudes. The results implicate the zero-hour initial conditions over the Antarctic high 


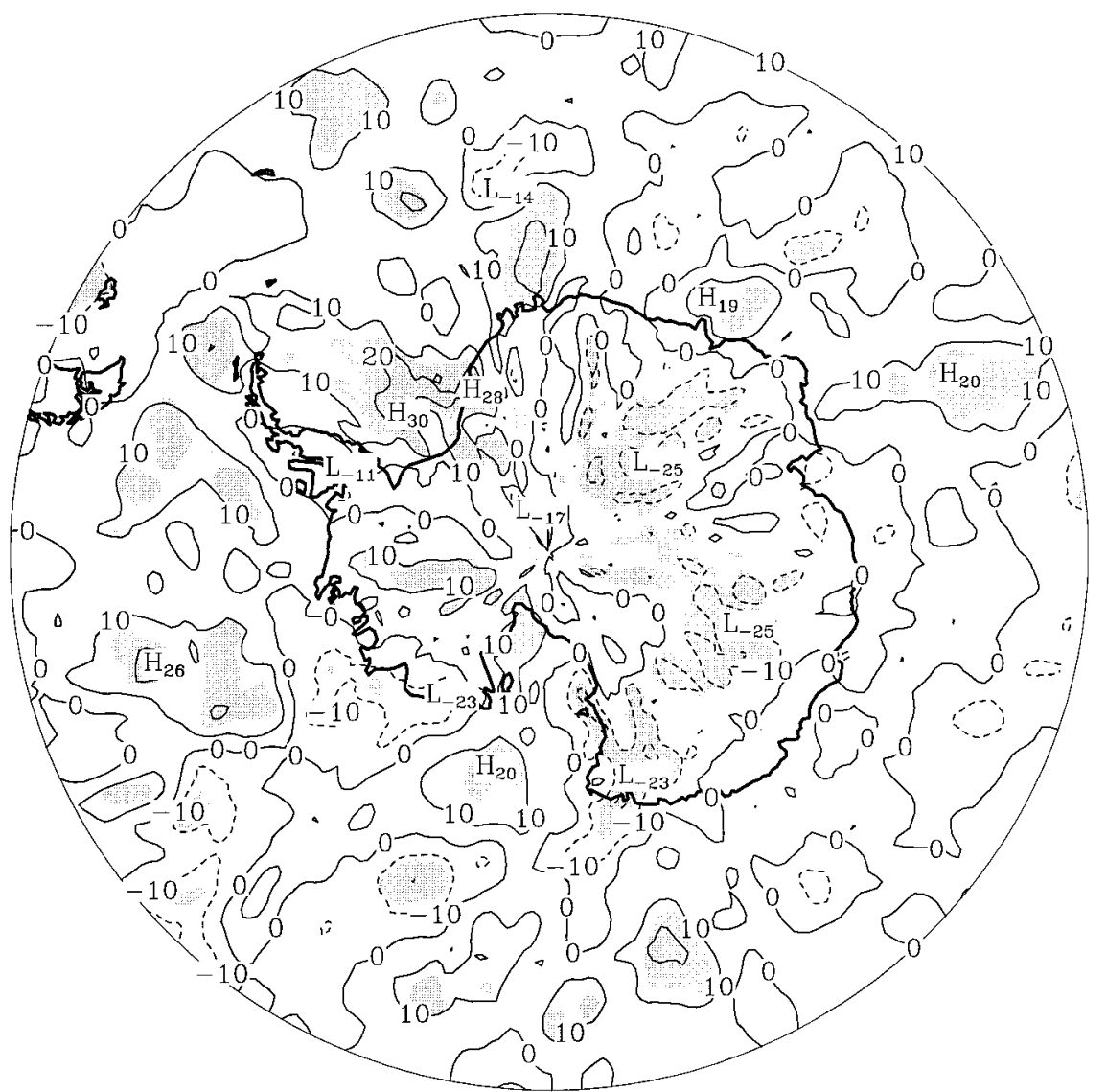

FIG. 18. The difference of NCEP day 3 average forecast middle cloud coverage minus day 1 , plotted for the region $50^{\circ} \mathrm{S}-$ South Pole for July 1994 . The contour interval is $10 \%$. Shaded areas indicate significance at the $95 \%$ confidence level based on a two-sided Student's $t$-test.

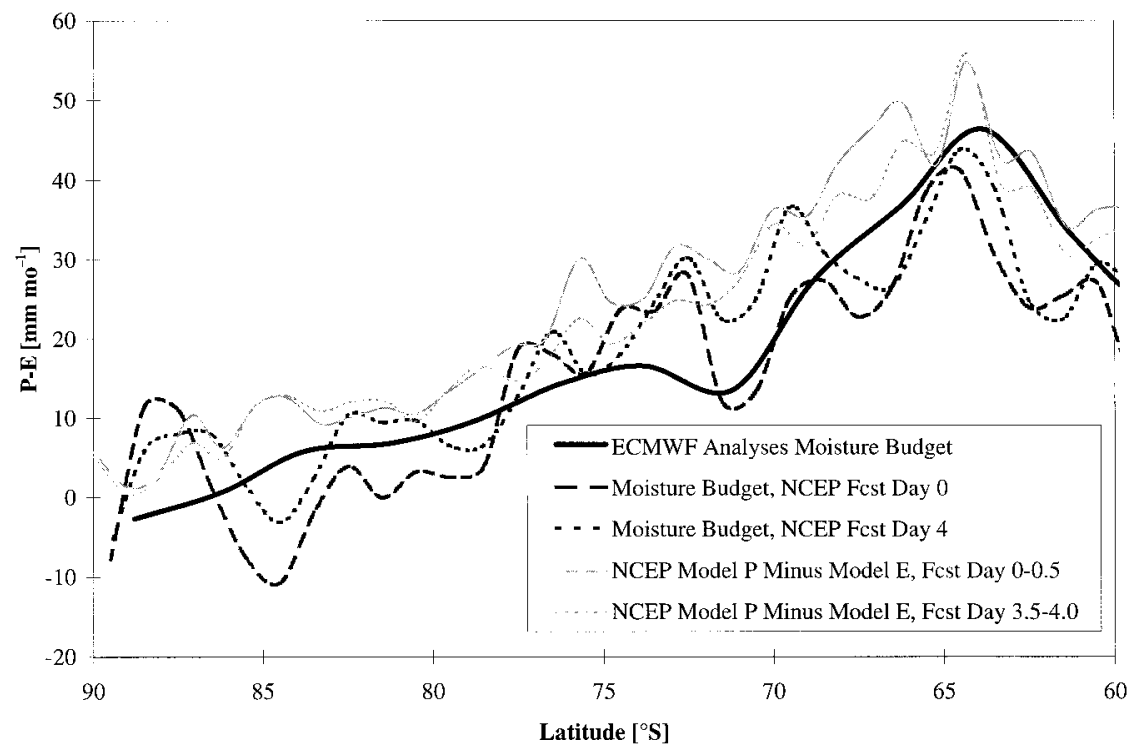

FIG. 19. Comparison of zonally averaged NCEP $P-E$ based on the derived atmospheric moisture budget and forecast values for various periods of the suite of forecasts for Jul 1994. 


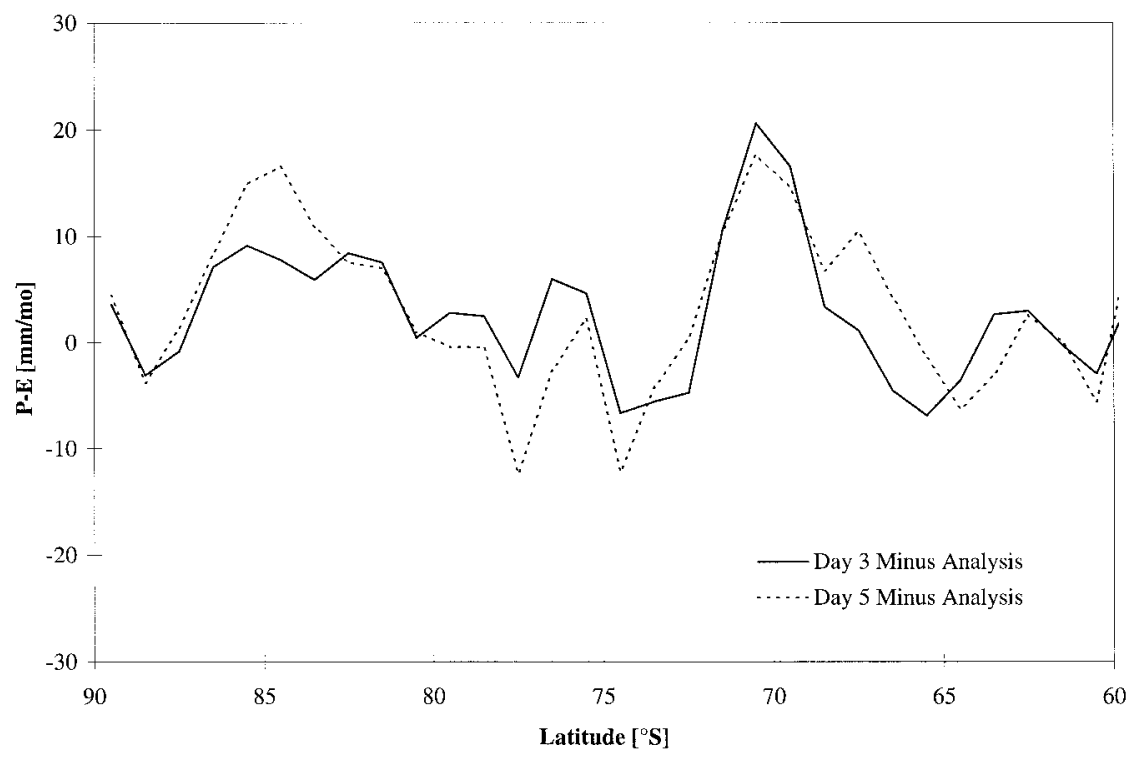

FIG. 20. Zonally averaged difference of NCEP $P-E$ derived from the atmospheric moisture budget for days 3 and 5 of the suite of forecasts minus analysis-derived values for Jul 1994.

plateau, particularly the temperature profile, as a major cause of the model adjustments. Apparent forecast model compensation for initial conditions produce the largest model biases in the Southern Hemisphere in several fields. The most significant forcing of Antarctic circulation arises from physical processes within the lowest few hundred meters of the atmosphere (e.g., Parish 1988). Thus, the adjustments seen in the surface pressure and temperature fields suggest severe discrepancies in the Antarctic forecasts. For the sparse number of observations over the Antarctic interior, however, it is apparent that the model drifts toward the observed climatology, again suggesting that deficient initial conditions play a major role. As the complement to this paper, Hines et al. (1999) examines the NCEP model surface energy balance and identifies areas where improvements in the model physical parameterizations are possible. Thus the observed deficiencies may be viewed as the combined result of the initial fields and the model physics.

It will be necessary to examine how recent modifications to the NCEP boundary layer parameterization (e.g., Caplan et al. 1997) have affected the high southern latitudes, although it is clear that several of the identified problems have subsequently been addressed. In particular, a correction scheme has been implemented in November 1997 to eliminate the spurious high-latitude wave pattern in operational analyses and forecasts. The near-surface temperature field is an additional area that has ungone considerable refinement due to changes in the boundary layer parameterization.

The rapid adjustment of a model to its initial conditions is a historical problem in atmospheric modeling, particularly with respect to the atmospheric moisture fields (e.g., Krishnamurti et al. 1988). The large mag- nitude and spatial distribution of the adjustments presented here for the NCEP model indicate difficulties that are specific to the high southern latitudes, however, which should be addressed. The central geographic location of Antarctica and its role as the southern tie point for observational networks underscores the importance of a realistic Antarctic depiction for hemispheric forecast quality. The results of this study have significant and cautioning implications for the use of reanalysis products in this region, which are further discussed by Hines et al. (1999).

Acknowledgments. FROST data were obtained from the British Antarctic Survey. ECMWF numerical analyses were obtained from NCAR. This research was sponsored by the National Science Foundation under Grant ATM-9422104.

\section{REFERENCES}

Augustine, N. R., and Coauthors, 1997: The United States in Antarctica: Report of the U.S. Antarctic Program External Panel. National Science Foundation, Washington, DC, 94 pp. [Available from National Science Foundation, Arlington, VA 22230.]

Beard, G. S., 1995: Southern Hemisphere climate summary by season from autumn 1994 to 1994-95: A warm Pacific (El Niño) episode peaks in early summer. Aust. Meteor. Mag., 44, 237-256.

Bourke, W. P., 1996: Review of the performance of the Bureau of Meteorology Global Assimilation and Prediction system (GASP). Research Report on 1994 Modelling Workshop, BMRC Research Rep. 52, 47 pp. [Available from Bureau of Meteorology Research Centre, GPO Box 1289K, Melbourne, Victoria 3001, Australia.]

Bromwich, D. H., and F. M. Robasky, 1993: Recent precipitation trends over the polar ice sheets. Meteor. Atmos. Phys., 51, 259274.

_ rology of the Southern Hemisphere, D. J. Karoly and D. G. 
Vincent, Eds., Meteor. Monogr., No. 49, Amer. Meteor. Soc., 175-200.

, F. M. Robasky, R. I. Cullather, and M. L. van Woert, 1995: The atmospheric hydrologic cycle over the Southern Ocean and Antarctica from operational numerical analyses. Mon. Wea. Rev. 123, 3518-3538.

Campana, K. A., Y.-T. Hou, K. E. Mitchell, S.-K. Yang, and R. Cullather, 1994: Improved diagnostic cloud parameterization in NMC's global model. Preprints, 10th Conf. on Numerical Weather Prediction, Portland, OR, Amer. Meteor. Soc., 324-325.

Caplan, P., J. Derber, W. Gemmill, S.-Y. Hong, H.-L. Pan, and D. Parrish, 1997: Changes to the 1995 NCEP operational mediumrange forecast model analysis-forecast system. Wea. Forecasting, 12, 581-594.

Connolley, W. M., 1996: The Antarctic temperature inversion. Int. J. Climatol., 16, 1333-1342.

Cullather, R. I., D. H. Bromwich, and M. L. van Woert, 1996: Interannual variability in Antarctic precipitation related to El Niño-Southern Oscillation. J. Geophys. Res., 101, $19109-$ 19118.

— - — , and R. W. Grumbine, 1997: Validation of operational numerical analyses in Antarctic latitudes. J. Geophys. Res., 102, $13761-13784$

Drewry, D. J., 1983: The surface of the Antarctic ice sheet. Antarctica: Glaciological and Geophysical Folio, Scott Polar Research Institute, Cambridge, United Kingdom, Sheet 2.

Genthon, C., and A. Braun, 1995: ECMWF analyses and predictions of the surface climate of Greenland and Antarctica. J. Climate, 8, 2324-2332.

Giovinetto, M. B., N. M. Waters, and C. R. Bentley, 1990: Dependence of Antarctic surface mass balance on temperature, elevation, and distance to open ocean. J. Geophys. Res., 95, 35173531.

Hines, K. M., R. W. Grumbine, D. H. Bromwich, and R. I. Cullather, 1999: Surface energy balance of the NCEP MRF and NCEPNCAR reanalyses in Antarctic latitudes during FROST. Wea. Forecasting, 14, 851-866.

Kalnay, E., and Coauthors, 1996: The NCEP/NCAR 40-Year Reanalysis Project. Bull. Amer. Meteor. Soc., 77, 437-471.

Kanamitsu, M., 1989: Description of the NMC global data assimilation and forecast system. Wea. Forecasting, 4, 334-342.

— , and Coauthors, 1991: Recent changes implemented into the global forecast system at NMC. Wea. Forecasting, 6, 425-435.

Krishnamurti, T., H. Bedi, W. Heckley, and K. Ingles, 1988: On the reduction of spinup time for evaporation and precipitation in a global spectral model. Mon. Wea. Rev., 116, 907-920.

Lubin, D., B. Chen, D. H. Bromwich, R. C. J. Somerville, W.-H. Lee, and K. M. Hines, 1998: The impact of Antarctic cloud radiative properties on a GCM climate simulation. J. Climate, 11, 447462.

Marsiat, I., and J. L. Bamber, 1997: The climate of Antarctica in the UGAMP GCM: Sensitivity to topography. Ann. Glaciol., 25, 7984.

Miyakoda, K., and J. Sirutis, 1981: Manual of the e-physics. NOAA/ GFDL, 91 pp. [Available from GFDL/NOAA, Princeton University, P.O. Box 308, Princeton, NJ 08540.]

Mo, K. C., and R. W. Higgins, 1996: Large-scale atmospheric moisture transport as evaluated in the NCEP/NCAR and NASA/DAO reanalyses. J. Climate, 9, 1531-1545.

Parish, T. R., 1988: Surface winds over the Antarctic continent: A review. Rev. Geophys., 26, 169-180.

— the Antarctic katabatic wind regime. J. Climate, 4, 135-146.

Phillpot, H. R., and J. W. Zillman, 1970: The surface temperature inversion over the Antarctic continent. J. Geophys. Res., 75, 4161-4169.

Radok, U., D. Jenssen, and B. McInnes, 1987: On the surging potential of the polar ice streams. Rep. DOE/ER/60197-H1, U.S. Department of Commerce, 62 pp. [Available from National Technical Information Service, U.S. Department of Commerce, Springfield, VA 22161.]

Stearns, C. R., L. M. Keller, G. A. Weidner, and M. Sievers, 1993: Monthly mean climatic data for Antarctic automatic weather stations. Antarctic Meteorology and Climatology: Studies Based on Automatic Weather Stations, Vol. 61, D. H. Bromwich and C. R. Stearns, Eds., Antarctic Research Series, Amer. Geophys. Union, 1-21.

Tibaldi, S., and F. Molteni, 1990: On the operational predictability of blocking. Tellus, 42A, 343-365.

—, E. Tosi, A. Navarra, and L. Pedulli, 1994: Northern and Southern Hemisphere seasonal variability of blocking frequency and predictability. Mon. Wea. Rev., 122, 1971-2003.

Tracton, M. S., 1990: Predictability and its relationship to scale interaction processes in blocking. Mon. Wea. Rev., 118, 16661695.

Trenberth, K. E., and J. G. Olson, 1988: Evaluation of NMC global analyses: 1979-1987. NCAR Tech. Note NCAR/TN-299+STR, $82 \mathrm{pp}$.

Turner, J., and Coauthors, 1996: The Antarctic First Regional Observing Study of the Troposphere (FROST) project. Bull. Amer. Meteor. Soc., 77, 2007-2032.

Tzeng, R. Y., D. H. Bromwich, T. R. Parish, and B. Chen, 1994: NCAR CCM2 simulation of the modern Antarctic climate. $J$. Geophys. Res., 99, 23 131-23 148.

van Loon, H., and D. J. Shea, 1987: The Southern Oscillation. Part VI: Anomalies of sea level pressure on the Southern Hemisphere and the Pacific sea surface temperature during the development of a warm event. Mon. Wea. Rev., 115, 370-379. 
Copyright of Weather \& Forecasting is the property of American Meteorological Society and its content may not be copied or emailed to multiple sites or posted to a listserv without the copyright holder's express written permission. However, users may print, download, or email articles for individual use. 